\title{
Hydroxylated-Cpd 5: Possible 'better' Arylator on Cell Growth Inhibition
}

\author{
Seung Wook Ham and Siyeon Lee \\ Department of Chemistry: Chthg-Ang Lhiversitv, Seoul 156-756, Korea \\ Received.April 30, 2004
}

Key Words : Cdc25 phosphatase. Naphthoquinone. Cell growth inhibition. Reduction potential

As important cell cycle regulators. $\mathrm{Cdc} 25 \mathrm{~s}$ are key $\mathrm{Cdk}$ activating proteins and act by dephosphorylation of conserved Cdk residues. Since Cdc25 protein was first found as the twenty-fifth protein to be related to the cell division cycle. ${ }^{1}$ three different members. $\mathrm{Cdc} 25 \mathrm{~A}$. $-\mathrm{B}$. and $-\mathrm{C}$ were identified in humans ${ }^{2}$ and several splice variants of $\mathrm{Cdc} 25$ proteins have also been reported. The evidence that $\mathrm{Cdc} 25 \mathrm{~A}$ and $-\mathrm{B}$ are overexpressed and likely important for the growth of different types of human cancer ${ }^{+}$has stimulated the search for $\mathrm{Cdc} 25$ inhibitors. However the literature on $\mathrm{Cdc} 25$ inhibition is in its infancy and inhibitor design strategies are just now emerging. ${ }^{5}$

Recently: several 1.4-naphthoquinones have proven to be effective at inhibiting $\mathrm{Cdc} 25$. including vitamin $\mathrm{K}_{3}{ }^{6}$ Among them. vitamin $\mathrm{K}$ derivative. Cpd 5 (2-(2-mercaptoethanol)-3methyl-1.4-naphthoquinone) was found to be one of the most growth inhibitors in vitro of various tumor cell lines in the range of $9-30 \mu \mathrm{M}^{i c}$ and markedly less active against PTPIB and other dual specificity phoaphatases. VHR and MKP-1. ${ }^{7}$ Previously: we also demonstrated that the 1.4naphthoquinone derivatives with the hydroxy group at $\mathrm{C}-5$ and/or C-8 of the benzene ring was more active than vitamin $\mathrm{K}_{3}$ on Cdc25A inhibition. ${ }^{6 \mathrm{~b}}$ Therefore. in the current study. we sy'nthesized mono- and dilydroxylated Cpd 5 derivatives 2 and 3 by addition of $\beta$-mercaptoethanol to the commercially available naphthoquinones in methanol. To examine the effects of these compounds on the growth of Hep3B cells in vitro. cells were cultured with several concentrations of Cpd 5 or hydroxylated $\mathrm{Cpd} 5$ derivatives and a grow th curve was drawn from the DNA amounts of each cell sample.

$$
\begin{aligned}
& \text { Cpd } 5(1), R_{1}=H, R_{2}=H \\
& 2, R_{1}=H, R_{2}=O H \\
& 3, R_{1}=O H, R_{2}=O H
\end{aligned}
$$

As shown in Figure 1, the $\mathrm{IC}_{\text {si }}$ values for monohydroxy and dihydroxy Cpd 5 were found to be $3 \mu \mathrm{M}$ and $1 \mu \mathrm{M}$. respectively showing them to be more potent growth inhibitors than the parent $\mathrm{Cpd} 5$.

It has been reported that $\mathrm{Cdc} 25 \mathrm{~A}$ regulates endogenous ERK phosphorylation status in cells. ${ }^{8}$ Therefore. we also measured the amount on Western blots of lysates from

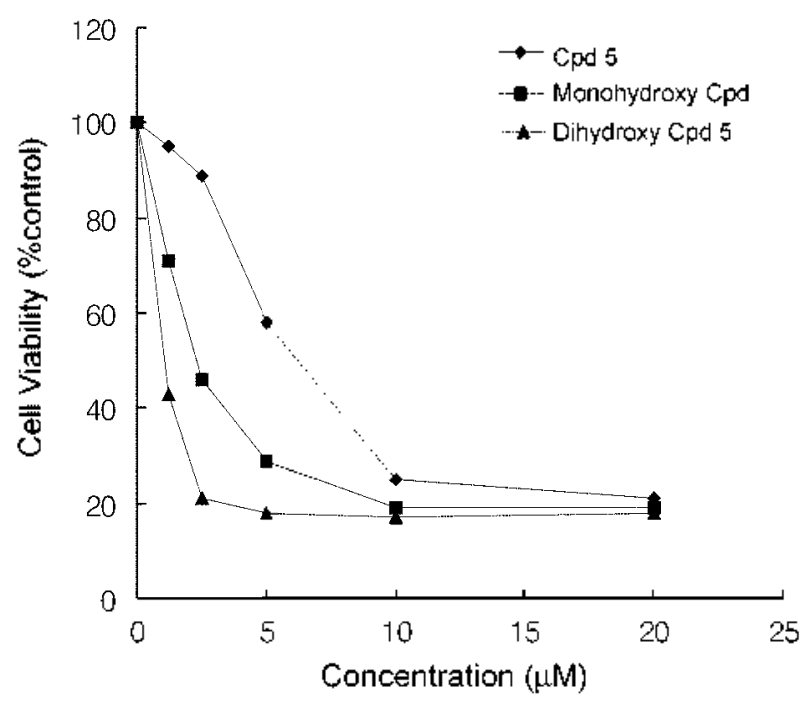

Figure 1. Monolayer cell growth was assayed after cells were plated at $5 \times 10^{4}$ cells/well on 6 -well culture plates. After $24 \mathrm{~h}$, the medium was replaced with a medium containing $C p d 5$ or hydoxylated $\mathrm{C} p \mathrm{~d} 5$ at various concentrations. After treatment for 3 days, cells were trypsinized and suspended in $1 \mathrm{~mL}$ of phosphatebuffered saline with $5 \%$ calf serum. Absorbance at $660 \mathrm{~nm}$ was measured spectrophotometrically. Control experiments demonstrated a linear correlation between Hep3B cell density and absorbance at $660 \mathrm{~nm}$

treated cells. using phospho-ERK antibody. As shown in Figure 2. phospho-ERK was induced after treatment with each of the compounds on Hep3B cells. while the ERK protein levels remained constant. indicating that the increase of ERK phosphorylation occurred at grow th inhibitory doses and dihydroxy $\mathrm{Cpd} 5(\mathbf{3})$ was the most potent inhibitor against $\mathrm{Cdc} 25 \mathrm{~A}$.

Although most $\mathrm{Cdc} 25$ inhibitors with the quinone moiety

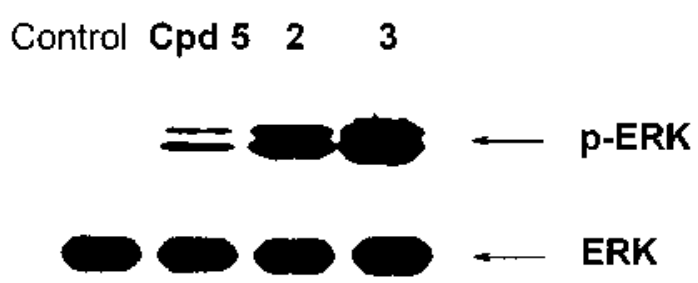

Figure 2. Effects of $\mathrm{Cpd} 5$, monohydroxy $\mathrm{Cpd} 5(2)$ and dihydroxy Cpd 5 (3) on ERK phosphorylation. Cells were treated with these compounds at $15 \mu \mathrm{M}$ for $24 \mathrm{~h}$. The cells were lysed and whole cell proteins ( $40 \mu \mathrm{g} / \mathrm{lane}$ ) were resolved by $10 \%$ SDS-PAGE. Westem blotting was performed with anti-phospho-ERK. 
Table 1. HOMO and LUMO Orbital Energies and One-Electron Reduction Potentials For Quniones

\begin{tabular}{cccc}
\hline & HOMO $(\mathrm{eV})$ & LUMO $(\mathrm{eV})$ & Potential $(\mathrm{mV})$ \\
\hline Cpd 5 & $-8.649 \mathrm{I}$ & -1.4826 & -161 \\
Dihydroxy Cpd 5 & -8.6216 & -1.5579 & -91 \\
\hline
\end{tabular}

have been reported to act by sulfhydryl arylation at the quinone nucleus. the redox properties can also generate toxic oxygen species, which may cause toxicity to normal tissues and thus reduce their therapeutic attractiveness. ${ }^{\text {]i }}$ Regarding oxidative stress of quinones, the single electron reduction enzymes initiates redox cycling and oxidative stress, ${ }^{11}$ and the relative one-electron reduction potentials of quinones control the position of the equilibrium defining futile cycling. ${ }^{12}$

$$
\mathrm{Q}^{\bar{B}}+\mathrm{O}_{2} \rightleftharpoons \mathrm{Q}+\mathrm{O}_{2}^{\bar{*}}
$$

Since the equilibrium constant $\mathrm{K}$ is approximately $10^{\text {sEiti.106, }}$ where $\Delta E=$ one-electron reduction potential of oxygen $(-0.155 \mathrm{~V})-$ one-electron reduction potential of quinone in volts. ${ }^{13}$ the superoxide formation will be increasingly favored at smaller reduction potentials of quinone. Recently. we determined that the potential for the one-electron reduction of quinones can simply be determined the electronic properties of the quinone system through theoretical calculation of LUMO energies using the semi-empirical AMl method. ${ }^{1+}$ We have extended the investigation to dilydroxy Cpd 5 from the calculation of its LUMO energy by the AMl method. resulting in the value of $-1.5579 \mathrm{eV}$ and $E_{1: 2}=.91 \mathrm{mV}$. which indicates that dihydroxy Cpd 5 is better arylator of cysteine-containing proteins than Cpd 5 . Compared with $\mathrm{Cpd} 5$. the higher one electron reduction potential for dilydroxy $\mathrm{Cpd} 5$ may be explained by internal hydrogen bonding in the dihydoxy naphthoquinone contributes to stabilization of the semiquinone. probably as a result of increased delocalization due to exchange of the hydroxyl hydrogen between neighboring oxygen atoms.

The frequency of overexpression has focused increasing attention on $\mathrm{Cdc} 25$ phosphatases as potential targets for cancer therapy. Despite success in development of quinones as $\mathrm{Cdc} 25$ inhibitors. the redox properties of the quinones can generate toxic oxygen species. resulting in the loss of selectivity of growth inhibitory effects on tumor compared to normal cells. In this study it demonstrated the possibility that modification by addition of appropriate substituents to the quinone could be a ker' in achieving better electronical character. as well as better potency.
Acknowledgement. This work was supported by ChungAng University (2002).

\section{References}

1. Russell. P. Nurse. P. Cell 1986. +5.145 .

2. (a) Galaktionov. K.: Beach, D. Cell 1991, 67. 1181. (b) Jinno, S: Suto. J: Nagata, A.; Igarashi, M.: Kanaoka, Y.: Nojima, H: Ohayama. H. EI $B O O J$. 1994. 13. 1549. (c) Nagata. A.: Igarashi. M.: Tinno. S.: Suto. K.: Okayama. H. New Biol 1991. 3. 959. (d) Sadhu. K.: Reed. S. I.: Richardson. H.: Russell. P. Proc. Katl. Acad Sci. LSA 1990, 87,5139

3. (a) Forrest, A. R.: McCormack, A. K.: DeSouza. C. P.: Sinnamon, J. M.: Tonks, I. D.; Hayward, N. K : Ellem, K. A.: Gabrielli, B. G. Biochem. Biophys. Res. Conmm. 1999. 260. 510. (b) Wegener. S.: Hampe. W: Hermann. D.: Schaller. H. C.: Wegener. S. Hampe. W.: Hermantn. D.: Schaller. H. C. Eur. J. Cell Biol. 2000. 79. 810 . (c) Hemandez, S.: Hernandez, L.: Bea, S.: Pinyol. M: Nayach. I.: Bellosillo, B.; Nadal, A.; Ferrer, A.; Fernandez, P. L.: Montserrat, E; Cardesa, A.; Campo, E. Iht d. Cancer 2000, 89. 148.

4. For the review. see: Prevost. G. P.: Brezak. M. C.: Goubin. F.: Mondesert. O.: Galcera. M. O.: Quaranta. M.: Alby. F.: Lavergne. O. Ducommun. B. Prog Cell Crele Res. 2003, $5,225$.

5. For the review see: (a) Eckstein. J. W. hnest. New Drugs 2000. 18. 149. (b) Pesttell, K. E.; Ducruet, A. P.: Wipt, P; Lazo, J. S. Oncogene 2012. 19. 6607. (c) Lyon. M. A.: Ducruet. A. P.: Wipt. P.: Lazo. J. S. Nat. Rev Dntg Discot: 2002. 1.961.

6. (a) Ham. S. W. Park. H. J.: Lim. D. H. Bioorg Chent 1997. 25. 33. (b) Ham, S. W. Park. J.: Lee, S. J.: Kim, W. Kang, K. Choi K. H. Bioorg. 1fed Chem. Lett 1998. 8, 2507. (c) Nishikawa, Y: Carr. B. I.: Wang, M.; Kar. S.: Finn, F.: Dowd, P.; Zheng, Z. B. Kerns. J.: Naganathan1. S. J. Biol. Chem 1995. 270. 28304. (d) Lazo. I. S.: Nemoto. K: Pestell. K. E.: Cooley. K: Southwick. E. C.: Mitchell. D. A.: Furey. W.: Gussio. R.: Zaharevitz. D. W.: Too. B.: Wipf, P. Hol Pharnacol, 2002, 61. 720. (e) Lazo. J. S.; Aslan. D. C.: Southwick. E. C: Cooley. K. A.; Ducruet, A. P.; Joo, B: Vogt, A.; Wipf. P. I. Med Chem 2001. Ht, 4042 .

7. Tamura. K.: Southwick. E. C.: Kerns. T.: Rosi. K.: Carr. B. I.: Wilcox. C.: Lazo. T. S. Cancer Res. 2000. 60. 1317.

8. Vogt. A.: Adachi. T.: Ducruet. A. P.: Chesebrough. T.: Nemoto. K.: Carr. B. I.: Lazo. J. S. J. Biol. Chen 2001. 276, 20541.

9. Biochemisty of Ounones. Morton. R. A.. Ed.: Academic Press: New York, 1965

10. Wardman. P. Cur Med. Chem 2001. 8.739

11. (a) Lind. C.: Hochstein. P.: Ernster. L. Akh. Biochent. Biophss 1982. 216. 178. (b) Thor. H.: Smith. M. T.: Hartzell. P.: Bellomo. G.: Jewell, S: Orrenius. S. J. Biol. Chent 1982, 257. 12419. (c) Morrison. H.: Jernstrom. B.; Nordenskjold, M.: Thor, H: Orrenius, S. Biochem. Phamacol. 1984. 33, 1763.

12. (a) Hochstein. P. Fundam. Appl. Toxicol 1983. 3. 215. (b) Lind. C.: Cadenas. E.: Hochstein. P.: Ernster. E. Mohods Enzwnol. 1990. 186.287

13. Wardman, P. J. Phus Chem Ref Data 1989. 18, 1637.

14. Ham. S. W.: Choe. J: Wang, M.-F; Peyregne, V: Carr. B. I. Bioorg. Hed. Chem. Lett. 2004, 1t, 4103 . 